\title{
DIRASAH
}

Volume 2, Number 1, Februari 2019

p-ISSN: 2615-0212 | e-ISSN: 2621-2838

https://ejournal.iaifa.ac.id/index.php/dirasah

\begin{tabular}{|c|c|c|}
\hline Accepted: & Revised: & Published: \\
Oktober 2018 & Desember 2019 & Februari 2019 \\
\hline
\end{tabular}

\section{Hubungan Antara Tingkat Religiusitas Orang Tua dengan Religiusitas Siswa}

\author{
Alfin Maskur \\ Institut Agama Islam Diponegoro Nganjuk, Indonesia \\ e-mail:alfinmaskur@gmail.com
}

\begin{abstract}
Children are individuals who determine the future and quality of the nation, so it is important to consider the development of the child, namely physical development, psychiatric and spirituality. A strong base of planting through the guidance and religious education, the role of family began to weaken because of the social, political and cultural changes that occurred. The family has lost its function in student emotion development especially in the adolescent phase. The purpose of this research is to test the relationship of parents ' religiality to the level of religiality of students of XI MAN Prambon class. Using the quantitative approach of the results of this research is as follows: (1) The level of religiality of parents of class XI MAN Prambon is categorized as excellent based on the mean value of 130, 718 which is guided by the absolute score criteria ; (2) The level of religiality of students of the class XI MAN Prambon is categorized very well based on the mean value of 127,971 which is guided by the absolute score criteria; (3) There is a significant relationship with the level of parents ' religiality and the level of religiality of class students of XI MAN Prambon with the correlation value of product moment of 0765 that is greater than the value of $R$ table and the value of Sig under 0.05 is 0.000 .
\end{abstract}

Keywords: religiusity, parents, students 


\section{Pendahuluan}

Anak-anak merupakan individu yang berarti sebagai generasi yang menentukan masa depan dan kualitas bangsa, maka sangat penting untuk memperhatikan perkembangan anak yaitu perkembangan jasmani, kejiwaan dan kerohanian. Penanaman dasar yang kuat melalui pemberian bimbingan dan didikan agama, peran keluarga mulai melemah dikarenakan perubahan sosial, politik dan budaya yang terjadi. Keluarga telah kehilangan fungsinya dalam perkembangan emosi siswa terutama pada fase remaja.

Busyairi Madjidi mengatakan bahwa: "Pelaksanan pendidikan tidak mungkin lepas dari faktor-faktor psikologis manusia di samping faktor lingkungan sekitar", ${ }^{1}$ maka dalam proses pengajaran perlu bahkan wajib berpegang pada petunjuk-petunjuk dari para ahli psikologi terutama psikologi pendidikan dan psikologi perkembangan, termasuk psikologi agama yang diaplikasikan melalui religiusitas seseorang. Hal ini sebagaimana yang disampaikan oleh Ary Ginanjar Agustin, bahwa :

Religiusitas dipusatkan untuk memunculkan perasaan kasih sayang, cinta, keindahan, keadilan, kejujuran dan lain sebagainya. Nilai-nilai tersebut tidak dibentuk oleh lingkungan sebagaimana dikatakan oleh para ilmuwan behavior, tetapi ia sudah built in dalam hati setiap manusia. ${ }^{2}$

Perkembangan kognitif remaja sudah berfungsi dengan baik sehingga memungkinkan mereka berpikir dalam membentuk kepribadian, remaja akan kritis terhadap hal apapun termasuk mengenai apa yang diyakininya dalam beragama. Adapun hakekat pendidikan sebagai usaha membina dan mengembangkan semua potensi siswa yaitu intelektual, keterampilan sosial, dan religiusitas seperti yang dijelaskan dalam Undang-undang Nomor 20 Tahun 2004 tentang Sistem Pendidikan Nasional dinyatakan bahwa:

Pendidikan Nasional berfungsi mengembangkan kemampun dan membentuk watak serta peradaban bangsa yang bermartabat dalamrangka mencerdaskan kehidupan bangsa, bertujuan untuk berkembangnya potensi peserta didik agar menjadi manusia yang beriman dan bertakwa kepada Tuhan Yang Maha Esa, berakhlak

\footnotetext{
${ }^{1}$ Busyairi Madjidi, Konsep Pendidikan Para Filosof Muslim (Yogyakarta: Al-Amin Press, 1991), 18.

${ }^{2}$ Ary Ginanjar Agustin, Rahasia Sukses Membangkitkan ESQ Power (Jakarta: Arga, 2006), 80.
} 
mulia, sehat, berilmu, cakap, kreatif, mandiri, dan menjadi warga Negara yang demokratis serta bertanggung jawab. ${ }^{3}$

Berdasarkan hal tersebut, maka lembaga pendidikan sekolah hendaknya mengacu pada usaha pengembangan tujuh aspek tersebut secara seimbang agar terbentuk anak didik cerdas, luwes, dan bersandar pada hati nurani dalam bersikap dan bertindak.

Dalam hal keagamaan, orang tua juga mempunyai peranan yang sangat penting, bukan hanya sebagai pendidik dan pembimbing saja, tetapi juga sebagai pembina kesiapan anak dalam melaksanakan ajaran-ajaran Islam, oleh karena itu orang tua harus mampu menjadi tauladan bagi putra-putrinya. Menurut Zakiyah Daradjat bahwa "pembentukan sikap, pembinaan moral dan pribadi pada umumnya, terjadi melalui pengalaman sejak kecil. Pendidik pertama adalah orang tua, kemudian guru. Semua pengalaman yang dilalui oleh anak waktu kecilnya, akan merupakan unsur penting dalam pribadinya." ${ }^{44}$ Kondisi psikologis remaja mempunyai pengaruh yang cukup besar dalam kehidupan beragama mereka karena remaja memiliki emosi yang sangat labil.

Orang tua mempunyai peran sangat besar dan paling bertanggung jawab dalam mendidik siswa di rumah, karena orang tua dan siswa mempunyai hubungan yang dekat, tempat terbaik bagi seorang anak tumbuh dewasa adalah di rumah dalam lingkungan keluarga. Orang tua adalah pusat kehidupan rohani anak dan sebagai penyebab berkenalnya dengan alam luar, maka setiap emosi dan pemikiran siswa dipengaruhi oleh sikap siswa terhadap orang tuanya pada masa kanak-kanak. Motivasi orang tua diperlukan dalam memberikan pendidikan agama pada anak karena melihat peranan orang tua yang sangat penting dapat mempengarahi perkembangan perilaku anak pada kehidupan masa depannya. Dijelaskan dalam al-Qur'an Surat Lukman ayat 13: "Dan (ingatlah) ketika Luqman berkata kepada anaknya, di waktu memberi pelajaran kepadanya: "Hai anakku, janganlah kamu mempersekutukan Allah, Sesungguhnya mempersekutukan (Allah) adalah benar-benar kezaliman yang besar""5

\footnotetext{
${ }^{3}$ Undang-undang RI Nomor 20 Tahun 2003 tentang Sisdiknas Beserta Penjelasannya (Bandung: Bulan Bintang, 2003), 7.

${ }^{4}$ Zakiyah Daradjat, Ilmu Jiwa Agama (Jakarta: Bulan Bintang, 1990), 62.

${ }^{5}$ Departemen Agama Republik Indonesia. Alqur'an dan Terjemahannya (Jakarta: J-Art, 2004), 412. QS. Lukman (13):13.
}

Dirasah, Vol. 2, No. 1, Februari 2019 
Anak merupakan amanah Allah SWT yang harus dijaga dan dibina, hati yang suci adalah permata yang sangat mahal harganya. Jika dibiasakan pada kejahatan dan dibiarkan seperti dibiarkannya binatang, ia akan celaka dan binasa. Sedangkan memeliharanya adalah dengan upaya pendidikan dan mengajarinya akhlak yang baik. ${ }^{6}$ Dalam hal ini, Islam tidak saja menjaga dan membina hubungan antar sesama manusia, tetapi juga memantapkan hubungan dengan Allah SWT. Pribadi-pribadi yang melakukan dua hal tersebut berarti sedang berupaya mengembangkan diri secara menyeluruh, baik secara fisik, mental, sosial, maupun secara spiritual.

Oleh karena itu, orang tua memegang faktor kunci yang menjadikan anak tumbuh dengan jiwa Islami sebagaimana sabda Rasulullah SAW: "Adam telah menyampaikan kepada kami, telah menyampaikan kepada kami Abi Zib'in dari Az-Zuhri dari Abi Salamah bin Abdirrahman dari Abu Hurairah R.A ia berkata: Bersabda Rasulullah SAW: Setiap anak dilahirkan di atas fitrahnya maka kedua orang tuanyalah yang menjadikannya seorang Yahudi, Nasrani atau Majusi. Sebagaimana binatang ternak yang melahirkan binatang ternak dengan sempurna. Apakah kalian melihat ada cacat pad nya?" (HR. Bukhari) ${ }^{7}$

Sebagai Upaya pemberian pendidikan agama pada siswa, orang tua harus mengerti dan memahami tentang pengetahuan keagamaan, hal-hal yang berhubungan dengan nilai-nilai agama dan yang mendukung pendidikan agama pada anak melalui pembiasaan dan latihan yang cocok dan sesuai dengan perkembangan jiwa siswa akan dapat juga mendukung pembinaan pribadi, karena pembiasaaan dan pelatihan tersebut akan membentuk sikap tertentu pada siswa yang lambat laun sikap tersebut akan bertambah jelas.

Pengaruh dan dukungan yang besar dari orang tua sangat penting dan sangat diperlukan siswa, tetapi orang tua kurang dapat memahaminya. Kemungkinan orang tua belum atau kurang mengerti akan pentingnya pendidikan pada siswa, di mana kesempatan paling besar untuk mendapat pendidikan agama adalah dari orang tuanya sebab anak-anak lebih bersama orang tua, sedangkan guru di sekolah hanya membantu melanjutkan, memperbanyak dan memperdalam apa yang diperoleh siswa dari orang tuanya. Dalam hal ini, orang tua perlu menyadari bahwa pendidikan keimanan merupakan pondasi awal yang harus dibangun oleh orang tua sejak dini karena iman dalam diri anak akan meniadi pengendali utama dalam segala gerak dan sikap. Dijelaskan dalam al-Qur'an Surat lukman ayat 14:

\footnotetext{
${ }^{6}$ H.D. Bastaman, Integrasi Psikologo dalam Islam (Yogyakarta: Pustaka Pelajar, 1995), 184.

${ }^{7}$ Imam al-Bukhari, Shahih Bukhari (Beirut: Dar Ahya al-Turarts al-Arabiy, tt), II: 125.
} 
"Dan Kami perintahkan kepada manusia (berbuat baik) kepada dua orang ibubapaknya; ibunya telah mengandungnya dalam Keadaan lemah yang bertambahtambah, dan menyapihnya dalam dua tahun. bersyukurlah kepadaku dan kepada dua orang ibu bapakmu. hanya kepada-Kulah kembalimu." 8

Di Madrasah Aliyah Negeri Prambon peran orang tua dalam memberikan pendidikan agama pada anak sangat penting, karena orang tua sebagai penuntun anak untuk menjalani dan mencapai tujuan hidup anak yang sesuai dengan ajaran agama. Tingkat religiusitas sangat penting dalam kehidupan terutama dalam dunia pendidikan. Namun bila dipandang pada saat sekarang ini orang tua kurang memperhatikan mengenai religiusitas anaknya, sebagaimana kenyataan yang terjadi pada saat sekarang ini banyak anak-anak yang sukses tetapi tidak memperoleh kebahagiaan dan ketenangan batin, walaupun mendapatkan kebahagiaan itupun sifatnya sementara. Maka Madrasah Aliyah Negeri Prambon berupaya mengembangkan anak didik yang cerdas, luwes, religius dan bersandar pada hati nurani dalam bersikap dan bertindak.

Madrasah Aliyah Negeri (MAN) Prambon sebagai lembaga pendidikan sekolah memegang fungsi dan peranan penting sebagai pelanjut dari proses pendidikan keluarga terutama karena adanya keterbatasan para orang tua mendidik anak-anaknya maka diserahkan ke lembaga pendidikan seiring dengan kepentingan kepribadian dan masa depan anak-anaknya. Terkadang para orang tua sangat selektif dalam menentukan tempat pendidikan untuk menyekolahkan anaknya, mengingat latar belakang orang tua siswa sebagian besar berasal dari keluarga religius. Untuk itu, mereka menyekolahkan anak-anaknya di lembaga pendidikan Islam. Adapula orang tua yang menyekolahkan anaknya di MAN Prambon dengan harapan sekolah tersebut dapat memberikan pengaruh positif terhadap kepribadian siswa terutama aspek religiusitas anak.

Kebutuhan spiritual merupakan kebutuhan mempertahankan keyakinan, mengembalikan keyakinan, memenuhi kewajiban agama, serta untuk menyeimbangkan kemampuan intelektual dan emosional yang dimiliki seseorang, sehingga dengan kemampuan ini akan membantu mewujudkan pribadi manusia seutuhnya. Dalam memberikan pendidikan agama pada anak orang tua terlebih dahulu memahami serta mampu melaksanakan nilai-nilai agama dengan benar sehingga orang tua termotivasi untuk memberikan pendidikan pada anak.

${ }^{8}$ QS. Lukman (31):14.

Dirasah, Vol. 2, No. 1, Februari 2019 
Selain itu, mendidik tidak hanya sekedar mengajar atau semata-mata mentransfer pengetahuan. Lebih dari itu, mendidik adalah penanaman nilai-nilai, sikap dan perilaku. Hakikat pendidikan yang seperti ini tidaklah cukup dilakukan dengan berkata-kata atau berceramah saja, perlu ada keteladanan dan pembiasaan yang baik di dalamnya.

Keteladanan seorang lebih baik dan efektif dalam mendidik dibandingkan dengan petuah atau nasehat dengan kata-kata. Keteladanan orang tua lebih mudah ditiru karena orang tua merupakan interaksi pertama bagi anak dalam membentuk kepribadiannya. Dalam memberikan pendidikan agama pada orang tua, terlebih dahulu memahami serta mampu melaksanakan nilai-nilai agama dengan benar sehingga orang tua termotivasi untuk memberikan pendidikan pada anak. Berdasarkan latar belakang di atas, peneliti ingin mengkaji lebih dalam hubungan antara tingkat religiusitas orang tua dengan religiusitas siswa kelas XI Madrasah Aliyah Negeri Prambon.

Adapun tujuan dalam perumusan masalah penelitian tesis yaitu untuk mengetahui tingkat religiusitas orang tua dan siswa kelas XI MAN Prambon serta hubungan antara keduanya.

\section{Landasan Teori}

\section{Tinjauan umum religiusitas}

\section{1. pengertian religiusitas}

Dalam kamus Ilmiah bahwa religiusitas diartikan sebagai "Ketaatan kepada agama." Menurut Gazalba seperti yang dikutip oleh Gufron "religiusitas berasal dari kata religi dalam bahasa Latin religio yang akar katanya adalah religure yang berati mengikat." ${ }^{10}$ Agama menurut Glock \& Stark dalam Djamaludin Ancok adalah "sistem simbol, sistem keyakinan, sistem nilai, dan sistem perilaku yang terlembagakan, yang semuanya itu berpusat pada persoalan-persoalan yang dihayati sebagai yang paling maknawi (ultimatemeaning)." 11

Gufron mengutip penjelasan Anshori yang membedakan antara istilah religi atau agama dengan religiusitas, bahwa "jika agama menunjuk pada

\footnotetext{
${ }^{9}$ Pius A. Partanto, dan M. Dhlan Al-Barry, Kamus Ilmiah Populer (Surabaya: Arkola, 1994), 667.

${ }^{10}$ M Nur Gufron \& Rini Risnawati, Teori-teori Psikologi (Malang: Ar-Ruzz Media, 2010), 167168.

${ }^{11}$ Djamaludin Ancok \& Fuat Nashori Suroso, Psikologi Islam: Solusi Islam atas Problemproblem Psikologi (Yogyakarta: Pustaka Pelajar, 2000), 76.
} 
aspek-aspek formal yang diberikan dengan aturan dan kewajiban, sedangkan religiusitas menunjuk pada aspek religi yang telah dihayati oleh seseorang dalam hati." 12 Menurut Harun Nasution sebagaimana dikutip Jalaluddin, bahwa agama adalah:

a. Pengakuan terhadap adanya hubungan manusia dengan kekuatan gaib yang harus dipatuhi.

b. Pengakuan terhadap adanya kekuatan goib yang menguasai manusia.

c. Mengikat diri pada suatu bentuk yang mengandung pengkuan pada suatu sumber yang berada diluardiri manusia dan mempengaruhi perbuatan-perbuatan manusia.

d. Kepercayaan pada sesuatu kekuatan gaib yang menimbulkan cara hidup tertentu.

e. Suatu sistem tingkah laku (code of conduct) yang berasal dari kekuatan gaib.

f. Pengakuan terhadap adanya kewajiban yang diyakini bersumber pada kekuatan gaib.

g. Pemujaan terhadap kekuatan gaib yang timbul dari perasaan lemah dan perasaan takut terhadap kekuatan misterius yang terdapat dalam alam sekitas manusia.

h. Ajaran-ajaran yang diwujudkan Tuhan kepada manusia melaluai seorang Rosul. ${ }^{13}$

Dengan demikian bahwa religio atau agama memiliki aturan-aturan dan kewajiban-kewajiban yang harus dipahami dan dilaksanakan oleh pemeluknya. Kesemuanya itu berfungsi mengikat seseorang atau sekelompok orang dalam hubungannya dengan Tuhan, sesama manusia, dan alam sekitarnya. Konsep religiusitas dapat diwujudkan dalam berbagai sisi kehidupan manusia. Jadi dalam pengertian ini, religiusitas adalah aktivitas keberagamaan ditinjau dari sudut nilai-nilai agama Islam yang harus diterapkan dalam kehidupan.

Keberagamaan juga meliputi setiap segi kehidupan seseorang. Hal tersebut seperti yang diungkapkan Djamaluddin dan Suroso bahwa:

\footnotetext{
12 Ibid, 168.

13 Jalaluddin, Psikologi Agama (Jakarta: Raja Grafindo Persada, 2001), 12-13.
}

Dirasah, Vol. 2, No. 1, Februari 2019 
Keberagamaan atau religiusitas diwujudkan dalam berbagai sisi kehidupan manusia. Aktivitas beragama bukan hanya terjadi ketika seseorang melakukan perilaku ritual (beribadah), tapi juga ketika melakukan aktifitas lain yang didorang oleh kekuatan supranatural. Bukan hanya yang berkaitan dengan aktivitas yang tampak dan dapat dilihat mata, tapi juga aktivitas yang tak tampak dan terjadi dalam hati hati seseorang. Karena itu, keberagamaan seseorang akan meliputi berbagai macam sisi atau dimensi. Dengan demikian, agama adalah sebuah sistem yang berdimensi banyak. ${ }^{14}$

Nur Ghufron mengutip pendapat Pruyser mengemukakan bahwa "manusia pada dasarnya adalah makhluk religius atau manusia merupakan makhluk yang berkembang menjadi religius." 15 Dengan demikian pendapat beberapa ahli di atas menunjukkan bahwa religious yaitu naluri atau dorongan untuk mencapai suatu keutuhan itulah yang merupakan akar dari religi. Jadi, pada dasarnya manusia merupakan makhluk yang beragama.

Dari berbagai definisi dan pendapat di atas dapat ditarik kesimpulan bahwa religiusitas adalah suatu kualitas keadaan seseorang dalam menghayati, memahami, serta mengamalkan nilai-nilai agama dalam kehidupan, yang menunjukkan ketaatan orang tersebut pada agama, interaksinya dengan Tuhan, sesama manusia dan alam semesta. Hal ini menunjukkan bahwa individu telah menghayati dan menginternalisasikan ajaran agamanya sehingga berpengaruh dalam segala tindakan dan pandangan hidupnya.

\section{2. dimensi religiusitas}

Glock dan Stark membagi lima dimensi religiusitas, yaitu:

a. Religius belief, yaitu tingkat penerimaan seseorang terhadap hal-hal yang dogmatis dalam agamanya, misalnya mengenai adanya Tuhan

b. Religius practise, yaitu tingkat pelaksanaan akan kewajibankewajiban ritual dalam agamanya.

c. Religius feeling, yaitu pengalaman keagamaan yang pernah dialami dan dirasakan, misalnya meras dekat dengan Tuhan, merasa do'anya dikabulkan.

${ }^{14}$ Djamaludin Ancok \& Fuat Nashori Suroso, Psikologi Islam: Solusi Islam atas ProblemProblem Psikologi (Yogyakarta: Pustaka Pelajar, 2000), 75.

${ }^{15}$ M. Nur Ghufron \& Rini Risnawita S, Teori-Teori Psikologi (Jogjakarta: Ar-Ruzz Media, 2010), 168. 
d. Religius effect, yaitu tingkat perilaku seseorang dimotivasi oleh ajaran agamanya dalam kehidupan sosial, misalnya mengunjungi tetangga yang sakit.

e. Religius knowledge, yaitu tingkat pengetahuan seseorang tentang ajaran agamanya, misalnya mengenai sifat-sifat Tuhan. ${ }^{16}$

Berdasarkan konsep religiusitas versi Glock dan Stark, Ancok dan Suroso mengatakan konsep tersebut mencoba melihat keberagaman seseorang bukan hanya dari satu atau dua dimensi, tapi mencoba memperhatikan segala dimensi. Keberagaman dalam Islam bukan hanya diwujudkan dalam bentuk ibadah ritual saja, tapi juga dalam aktivitasaktivitas lainnya. Sebagai suatu sistem yang menyeluruh, Islam mendorong pemeluknya untuk beragama secara menyeluruh pula. Karena itu, hanya konsep yang mampu memberi penjelasan menyeluruhlah yang mampu memahami keberagaman umat Islam.

Untuk memahami Islam dan umat Islam, konsep yang tepat adalah konsep yang mampu memahami adanya beragam dimensi dalam Islam. Menurut Ancok dan Suroso, rumusan Glock dan Stark yang membagi keberagaman menjadi lima dimensi dalam tingkat tertentu mempunyai kesesuaian dalam Islam. ${ }^{17}$ Peneliti kemudian mengelaborasi pemikiran Djamaluddin Ancok dan Saroso dalam merumuskan dimensi agama Islam sebagai berikut:

a. Dimensi keyakinan atau akidah Islam (The Ideological Dimension). Dimensi keyakinan atau akidah Islam menunjuk pada seberapa tingkat keyakinan Muslim terhadap kebenaran ajaran-ajaran agamanya, terutama terhadap ajaran-ajaran yang bersifat fundamental dan dogmatik. Di dalam keberislaman, isi dimensi keimanan menyangkut keyakinan tentang Allah, para malaikat, Nabi/Rasul, kitab-kitab Allah, surga dan neraka, serta qadha dan qadar.

b. Dimensi peribadatan atau syariah (Religious Practice). Dimensi peribadatan atau syariah menunjuk pada seberapa tingkat kepatuhan Muslim dulam mengerjakan kegiatan-kegiatan ritual sebagaimana

${ }^{16}$ R. Stark, dan C.Y. Glock, American Piety: The Nature of Religious Comitment (California: University of California Press, 1968), 53-54.

${ }^{17}$ Djamaluddin Ancok dan Fuad Nashari Suroso, Psikologi Islami (Yogjakarta: Pustaka Pelajar 1995), 76.

Dirasah, Vol. 2, No. 1, Februari 2019 
disuruh dan dianjurkan oleh agamanya. Dalam keberislaman, dimensi peribadatan menyangkut pelaksanaan shalat, puasa, zakat, haji, membaca al-Qur'an, doa, zikir, ibadah kurban, iktikaf di masjid di bulan puasa, dan sebagainya.

c. Dimensi pengamalan atau akhlak (Religious Effect). Dimensi pengamalan atau akhlak menunjuk pada seberapa tingkatan Muslim berperilaku dimotivasi oleh ajaran-ajaran agamanya, yaitu bagaimana individu berelasi dengan dunianya, terutama dengan manusia lain. Dalam keberislaman, dimensi ini meliputi perilaku suka menolong, bekerjasama, berderma, menyejahterakan dan menumbuhkembangkan orang lain, menegakkan keadilan dan kebenaran, berlaku jujur, memaafkan, menjaga lingkungan hidup, menjaga amanat, tidak mencuri, tidak korupsi, tidak menipu, tidak berjudi, tidak meminum minuman yang memabukkan, mematuhi norma-norma Islam dalam berjuang untuk hidup sukses menurut ukuran Islam.

d. Dimensi pengetahuan atau ilmu (Religious Knowledge). Dimensi pengetahuan atau ilmu menunjuk pada seberapa tingkat pengetahuan dan pemahaman Muslim terhadap ajaran-ajaran agamanya, terutama mengenai ajaran-ajaran pokok dari agamanya, sebagaimana termuat dalam kitab sucinya. Dalam keberisiaman, dimensi ini menyangkut pengetahuan tentang isi al-Qur'an, pokok-pokok ajaran yang harus diimani dan dilaksanakan (rukun Islam dan rukun Iman), hukum-hukum Islam, sejarah Islam, dan sebagainya.

e. Dimensi penghayatan . Dimensi penghayatan menunjuk pada seberapa jauh tingkat Muslim dalam merasakan dan mengalami perasaan-perasaan dan pengalaman-pengalaman religius. Dalam keberislaman, dimensi ini terwujud dalam perasaan dekat/akrab dengan Allah, perasaan doa-doanya sering terkabul, perasaan tenteram bahagia karena menuhankan Allah, perasaan bertawakkal (pasrah diri secara positif) kepada Allah, perasaan khusuk ketika melaksanakan shalat atau berdoa, perasaan tergetar ketika mendengar adzan atau ayat-ayat Al-Qur'an, perasaan bersyukur kepada Allah, pcrasaan mendapat peringatan atau pertolongan Allah swt. ${ }^{18}$

${ }^{18}$ Djamaluddin Ancok dan Fuad Nashari Suroso, Psikologi Islami (Yogjakarta: Pustaka Pelajar 1995), 76-80. 


\section{3. faktor-faktor yang mempengaruhi tingkat religiusitas}

Menurut Thoules, faktor-faktor yang mempengaruhi tingkat religiusitas adalah sebagai berikut:

a. Faktor sosial, mencakup semua pengaruh sosial dalam perkembangan sikap keagamaan yaitu pendidikan atau pengetahuan tentang agama, tradisi-tradisi sosial untuk menyesuaikan diri dengan berbagai pendapat dan sikap yang disepakati oleh lingkungan.

b. Faktor alam, yaitu berbagi pengalaman yang menambah sikap keagamaan rnengenai keindahan, keselarasan dan kebaikan dunia lain.

c. Faktor moral, yaitu pengalaman konflik antara rangsanganrangsangan perilaku yang dianggap akan membimbing ke arah yang baik.

d. Faktor afektif, yaitu pengalaman batin emosional yang tampak lebih terikat secara langsung dengan tuhan atau dengan sejumlah wujud dan pada sikap keagamaan atau disebut pengalaman-pengalaman agama yang dalam Islam disebut tasawuf. ${ }^{19}$

Keempat faktor tersebut di atas, faktor sosial sangat dominan dalam pembentukan religiusitas remaja, karena sangat erat hubungannya dengan lingkungan pergaulan remaja.

\section{Pengaruh tingkat religiusitas orang tua terhadap tingkat religiusitas anak}

Peneliti berasumsi bahwa tingkat religiusitas anak sangat dipengaruhi oleh tingkat religiusitas orang tua. Hal itu didasarkan pada beberapa teori, yang salah satunya dicetuskan oleh ilmuwan Albert Bandura melalui teori pembelajaran sosial serta teori modelling.

\section{a. Teori Belajar sosial}

Menurut Albert Bandura "tingkah laku manusia bukan semata-mata reflex otomatis atas stimulus, melainkan juga akibat reaksi yang timbul akibat interaksi antar lingkungan dengan skema kognitif manusia itu

${ }^{19}$ Robert.H. Thouless, Pengantar Psikologi Agama, Terj. Machnun Husein (Jakarta: Rajawali Press, 1992), 72.

Dirasah, Vol. 2, No. 1, Februari 2019 
sendiri. ${ }^{20}$ Prinsip dasar belajar hasil temuan Bandura termasuk belajar sosial dan moral. Ridwan Munir mengatakan bahwa:

Teori Pembelajaran Sosial merupakan perluasan dari teori belajar perilaku yang tradisional (behavioristik). Teori pembelajaran sosial ini dikembangkan oleh Albert Bandura. Teori ini menerima sebagian besar dari prinsip-prinsip teoriteori belajar perilaku, tetapi memberikan lebih banyak penekanan pada kesan dan isyarat-isyarat perubahan perilaku, dan pada proses-proses mental internal. Jadi dalam teori pembelajaran sosial kita akan menggunakan penjelasanpenjelasan reinforcement eksternal dan penjelasan-penjelasan kognitif internal untuk memahami bagaimana belajar dari orang lain. ${ }^{21}$

Dalam pandangan belajar sosial manusia itu tidak didorong oleh kekuatan-kekuatan dari dalam dan juga tidak dipengaruhi oleh stimulusstimulus lingkungan. Teori belajar sosial menekankan bahwa lingkungan-lingkungan yang dihadapkan pada seseorang secara kebetulan; lingkungan-lingkungan itu kerap kali dipilih dan diubah oleh orang itu melalui perilakunya sendiri. Menurut Bandura, sebagaimana dikutip oleh Surya Subrata bahwa "sebagian besar manusia belajar melalui pengamatan secara selektif dan mengingat tingkah laku orang lain." 22

Inti dari pembelajaran sosial adalah pemodelan (modelling), dan pemodelan merupakan salah satu langkah penting dalam pembelajaran terpadu. Ada dua jenis pembelajaran melalui pengamatan, yaitu:

1) Pembelajaran melalui pengamatan dapat terjadi melalui kondisi yang dialami orang lain. Contohnya: seorang pelajar melihat temannya dipuji dan ditegur oleh gurunya karena perbuatannya, maka ia kemudian meniru melakukan perbuatan lain yang tujuannya sama ingin dipuji oleh gurunya. Kejadian ini merupakan contoh dari penguatan melalui pujian yang dialami orang lain.

2) Pembelajaran melalui pengamatan meniru perilaku model meskipun model itu tidak mendapatkan penguatan positif atau penguatan

\footnotetext{
${ }^{20}$ C. George Boeree, Personality Theories: Melacak Kepribadian Anda bersama Psikolog Dunia. Terj. Inyiak Ridwan Muzir (Yogyakarta: Ar-Ruz Media, 2008), 239.

21 Ibid, 239-240.

${ }^{22}$ Surya Suryabrata, Psikologi Pendidikan (Jakarta: Rajawali Pers, 2010), 59.
} 
negatif saat mengamati itu sedang memperhatikan model itu, mendemonstrasikan sesuatu yang ingin dipelajari oleh pengamat tersebut dan mengharapkan mendapat pujian atau penguatan apabila menguasai secara tuntas apa yang dipelajari itu. Model tidak harus diperagakan seseorang secara langsung, kita dapat juga menggunakan seseorang pemeran atau visualisasi tiruan sebagai model. $^{23}$

Seperti pendekatan teori pembelajaran terhadap kepribadian, teori pembelajaran sosial berdasarkan pada penjelasan yang diutarakan oleh Bandura yang dikutip oleh Muhibbin Syah bahwa:

Sebagian besar daripada tingkah laku manusia adalah diperoleh dari dalam diri, dan prinsip pembelajaran sudah cukup untuk menjelaskan bagaimana tingkah laku berkembang. Akan tetapi, teori-teori sebelumnya kurang memberi perhatian pada konteks sosial dimana tingkah laku ini muncul dan kurang memperhatikan bahwa banyak peristiwa pembelajaran melalui perantaraan orang lain. ${ }^{24}$

Maksudnya, sewaktu melihat tingkah laku orang lain, individu akan belajar meniru tingkah laku tersebut atau dalam hal tertentu menjadikan orang lain sebagai model bagi dirinya. Pendekatan teori sosial terhadap proses perkembangan sosial dan moral siswa ditekankan pada perlunya conditioning ${ }^{25}$ (pembiasaan merespons) dan imitation $^{26}$ (peniruan).

Prinsip belajar menurut Bandura adalah usaha menjelaskan belajar dalam situasi alami, hal ini berbeda dengan situasi di laboratorium atau

${ }^{23}$ Universitas Muhamadiyah Malang, Psikologi Kepribadian (Malang:UMM Press, 2011), 283287.

${ }^{24}$ MuhibbinSyah, Psikologi Belajar (Jakarta: Rajawali Pers, 2009), 37.

${ }^{25}$ Conditioning; prosedur belajar dalam mengembangkan perilaku sosial dan moral pada dasarnya sama dengan prosedur belajar dalam mengembangkan perilaku-perilaku lainnya, yakni dengan reward (ganjaran / memberi hadiah atau mengganjar) dan punishment (hukuman / memberi hukuman) untuk senantiasa berpikir dan memutuskan perilaku sosial mana yang perlu ia perbuat.

26 Imitation; proses imitasi atau peniruan. Dalam hal ini, orang tua dan guru seyogianya memainkan peran penting sebagai seorang model atau tokoh yang dijadikan contoh berperilaku sosial dan moral bagi siswa. Sebagai contoh, seorang siswa mengamati gurunya sendiri menerima seorang tamu, lalu menjawab salam, menjabat tangan, beramah tamah, dan seterusnya yang dilakukan guru tersebut diserap oleh memori siswa.

Dirasah, Vol. 2, No. 1, Februari 2019 
pada lingkungan social yang banyak memerlukan pengamatan tentang pola perilaku beserta konsekuensinya.

\section{b. modelling (peniruan)}

Albert Bandura dan Richard Walters melakukan eksperimen pada anak-anak yang juga berkenaan dengan peniruan. Hasil eksperimen mereka mendapati, Ridwan Muzir mengatakan bahwa "peniruan dapat berlaku hanya melalui pengamatan terhadap perilaku model (orang yang ditiru) meskipun pengamatan itu tidak dilakukan terus menerus. Proses belajar semacam ini disebut observational learning atau pembelajaran melalui pengamatan." 27

Bandura menyarankan agar teori pembelajaran sosial diperbaiki memandang teori pembelajaran sosial yang sebelumnya hanya mementingkan perilaku tanpa mempertimbangan aspek mental seseorang. Menurut Bandura, dalam Ridwan Muzir bahwa: "perlakuan seseorang adalah hasil interaksi faktor dalam diri (kognitif) dan lingkungan. pandangan ini menjelaskan, beliau telah mengemukakan teori pembelajaran peniruan, beliau telah menjalankan kajian bersama Walter,"28 dalam teori ini kajian eksperimentasi terhadap perlakuan anak-anak apabila mereka menonton orang dewasa memukul, mengetuk dengan palu besi dan menumbuk sambil menjerit-jerit dalam video. Setelah menonton video anak-anak ini diarah bermain di kamar permainan dan terdapat patung seperti yang ditayangkan dalam video. Setelah anak-anak tersebut melihat patung tersebut, mereka meniru aksiaksi yang dilakukan oleh orang yang mereka tonton dalam video. Berdasarkan teori ini terdapat beberapa cara peniruan yaitu meniru secara langsung. ${ }^{29}$

Proses peniruan yang seterusnya ialah elisitasi. Proses ini timbul apabila seseorang melihat perubahan pada orang lain. Contohnya seorang anak-anak melihat temannya melukis bunga dan timbul keinginan dalam diri anak-anak tersebut untuk melukis bunga. Oleh karena itu, peniruan berlaku apabila anak-anak tersebut melihat

${ }^{27}$ George Boeree, Personality Theories: Melacak Kepribadian, 240.

${ }^{28}$ Ibid, 245.

${ }^{29}$ Ibid,. 
temannya melukis bunga. Menurut bandura seperti yang dikutip Rizwan Munir, bahwa:

Dalam teori belajar sosial, perbuatan melihat saja menggunakan gambaran kognitif dari tindakan, secara rinci dasar kognitif dalam proses belajar dapat diringkas dalam empat tahap, yaitu:

1) Perhatian (Attention) Subjek harus memperhatikan tingkah laku model untuk dapat mempelajarinya. Subjek memberi perhatian tertuju kepada nilai, harga diri, sikap, dan lain-lain yang dimiliki.

2) Mengingat (Retention) Subjek yang memperhatikan harus merekam peristiwa itu dalam sistem ingatannya. Ini membolehkan subjek melakukan peristiwa itu kelak bila diperlukan atau diinginka. Kemampuan untuk menyimpan informasi juga merupakan bagian penting dari proses belajar.

3) Reproduksi gerak (Reproduction) Setelah mengetahui atau mempelajari sesuatu tingkahlaku, subjek juga dapat menunjukkan kemampuannya atau menghasilkan apa yang disimpan dalam bentuk tingkah laku. Contohnya, mengendarai mobil, bermain tenis. Jadi setelah subyek memperhatikan model dan menyimpan informasi, sekarang saatnya untuk benar-benar melakukan perilaku yang diamatinya. Praktek lebih lanjut dari perilaku yang dipelajari mengarah pada kemajuan perbaikan dan keterampilan.

4) Motivasi, Motivasi juga penting dalam pemodelan Albert Bandura karena ia adalah penggerak individu untuk terus melakukan sesuatu. ${ }^{30}$

Dengan demikian peneliti mengambil suatu pemahaman bahwa karakteristik yang ditonjolkan dalam pembelajaran Modelling menurut Bandura antara lain:

1) Unsur pembelajaran utama ialah pemerhatian dan peniruan

2) Tingkah laku model boleh dipelajari melalui bahasa, teladan dan nilai

3) Pelajar meniru suatu kemampuan dari kecakapan yang didemonstrasikan guru sebagai model

${ }^{30}$ Ibid, 241-243.

Dirasah, Vol. 2, No. 1, Februari 2019 
4) Pelajar memperoleh kemampuan jika memperoleh kepuasan dan penguatan yang positif

5) Proses pembelajaran meliputi perhatian, mengingat, peniruan, dengan tingkah laku atau timbal balik yang sesuai, diakhiri dengan penguatan yang positif.

Selain terdapat tahapan, modelling juga terdiri dari beberapa jenis. Jenis-jenis Peniruan (modeling) menurut Albert Bandura seperti yang dikutip oleh Muhibbin Syah adalah sebagai berikut:

1) Peniruan langsung, Ciri khas pembelajaran ini adalah adanya modeling, yaitu suatu fase di mana seseorang mencontohkan sesuatu melalui demonstrasi bagaimana suatu ketrampilan itu dilakukan. Meniru tingkah laku yang ditunjukkan oleh model melalui proses perhatian. Contoh: Meniru gaya penyanyi yang disukai.

2) Peniruan tak langsung adalah melalui imaginasi atau perhatian secara tidak langsung. Contoh: memperhatikan seorang guru mengajarkan rekannya.

3) Peniruan gabungan, peniruan jenis ini adalah dengan cara menggabungkan tingkah laku yang berlainan yaitu peniruan langsung dan tidak langsung. Contoh : Pelajar meniru gaya gurunya melukis.

4) Peniruan sesaat/seketika. Tingkah laku yang ditiru hanya sesuai untuk situasi tertentu saja. Contoh: Meniru Gaya Pakaian di TV, tetapi tidak boleh dipakai di sekolah.

5) Peniruan Berkelanjutan. Tingkah laku yang ditiru boleh ditonjolkan dalam situasi apapun. Contoh: Pelajar meniru gaya bahasa gurunya. ${ }^{31}$

Menurut Kamsih Astutin: "teori belajar sosial membantu memahami terjadinya perilaku agresif dan penyimpangan psikologi dan bagaimana memodifikasi perilaku, teori Bandura menjadi dasar dari perilaku pemodelan yang digunakan dalam berbagai pendidikan secara massal." 32 Untuk itu karena melibatkan atensi, ingatan dan motivasi, maka teori Bandura termasuk dalam kerangka teori behavior-kognitif.

${ }^{31}$ MuhibbinSyah, Psikologi Belajar, 112.

${ }^{32}$ Kamsih Astuti, Psikologi Sosial (Yogyakarta: Universitas Mercu Buana, 2009), 211. 
Sebagai contoh: penerapan teori belajar sosial dalam iklan televisi. Iklan selalu menampilkan artis-artis popular dan disukai masyarakat, hal ini untuk mendorong konsumen agar membeli sabun supaya mempunyai kulit seperti "para artis" atau minum obat masuk anginnya "orang pintar".

Penerapan Teori Bandura dalam Pembelajaran Proses pembentukan perilaku religius diantaranya adalah dengan modeling. Kalau siapapun yang ada di rumah atau di lingkungan, anak sudah terbiasa dengan lingkungan religius sejak kecil maka hal ini akan diobservasi oleh anak secara terus menerus dalam hidupnya. Kemudian anak ini difasilitasi dengan banyak media ibadah baik yang alami maupun buatan untuk mendorong minat religiusnya, misalnya berupa buku bacaan islami, peralatan sholat dan kelengkapannya, serta mengaji di surau atau Masjid.

Orang tua berperan ganda, sebagai model sekaligus sebagai pamong belajar. Tanpa ada ancaman, hukuman, ketegangan, ketakutan akan membuat anak nyaman, tenang, untuk belajar dengan pamongnya. Dominansi kasih sayang, kelembutan, contoh yang nyata, kejujuran, kesantunan, pujian, penghargaan, senyuman akan sangat mendorong munculnya perilaku yang diharapkan. Kesinambungan proses seperti ini akan mengkristal dalam jiwa dan pikir anak sehingga menjadi perilaku yang permanen dalam hidupnya.

Jadi dapat disimpulkan bahwa individu belajar mengumpulkan informasi melalui observasi, baik tentang konsekuensi perilakunya sendiri maupun perilaku individu lain. Informasi yang diperoleh kemudian diterapkan di berbagai situasi yang membutuhkan perilaku tersebut. Perilaku yang mendapat reinforcement akan disimbolisasikan ke dalam memori sehingga informasi tersebut dapat membantu individu menentukan suatu perilaku tertentu pada situasi tertentu yang menghasilkan konsekuensi tertentu pula.

\section{Metode Penelitian}

Permasalahan dalam penelitian ini diangkat melalui pendekatan kuantitatif. Penelitian ini berusaha untuk mengungkap hubungan tingkat religiusitas orang tua untuk mengungkap kadar keberagamaan orang tua dalam lingkungan 
keluarga terhadap religiusitas siswa untuk menunjukan pada kadar keterikatan siswa terhadap ajaran agamanya.

Tingkat religiusitas diukur dengan menggunakan angket teknik pengambilan sampelnya ditetapkan secara random sampling yaitu memilih sampel berdasarkan tingkat kelas, yakni kelas XI Madrasah Aliyah Negeri Prambon tertentu kemudian setiap siswa dalam kelas dipilih secara acak berdasarkan populasi yang ada.

Adapun variabel yang diuji dalam penelitian ini terdapat dua variabel dalam penelitian ini dapat dirancangkan sebagai berikut:

1. Variabel bebas (independent variable) (X) Bambang Prasetyo menjelaskan: "Variabel bebas adalah variabel yang ada atau terjadi mendahului variabel terikatnya atau mempengaruhi variabel lain." ${ }^{, 33}$ Keberadaan variabel ini dalam penelitian kuantitatif merupakan variabel yang menjelaskan terjadinya fokus atau topik penelitian. Adapun variabel bebas dalam penelitian ini adalah tingkat religiusitas orang tua.

2. Variabel terikat (dependent variable) (Y) menurut Saifudin Azwar yaitu "variabel yang diakibatkan atau dipengaruhi oleh variabel yang lain." 34 Variabel penelitian yang diukur untuk mengetahui besarnya efek atau pengaruh variabel lain. Variabel ini berubah atau muncul akibat dari pengaruh variabel bebas. Adapun variabel terikat dalam penelitian ini adalah tingkat religiusitas siswa kelas XI MAN Prambon Nganjuk.

Populasi merupakan keseluruhan individu atau obyek yang diteliti yang memiliki beberapa karakteristik yang sama. Latipun mengatakan: "Populasi dibatasi sebagai sejumlah atau individu yang sedikitnya mempunyai sifat yang sama." 35 Populasi dalam penelitian ini adalah seluruh kelas XI MAN Prambon Nganjuk tahun ajaran 2012/2013 yang terdiri dari lima kelas yang jumlah siswanya sebanyak 136 siswa.

Dalam penelitian ini penulis mengambil sampel 103 dari seluruh populasi yang berjumlah 136 siswa. Adapun teknik yang digunakan dalam pengambilan sampel adalah teknik Random Sampling yaitu mengambil sampel secara acak tanpa memperhatikan golongan atau derajat siswa. Siapa saja yang menjadi

\footnotetext{
${ }^{33}$ Bambang Prasetyo, Metode penelitian Kuantitatif (Jakarta : Rajawali Press, 2010), 67

${ }^{34}$ Saifudin Azwar, Metode Penelitian (Yogyakarta : Pustaka Pelajar, 1998 ), 62.

${ }^{35}$ Latipun, Psikologi Eksperimen (Malang: UMM Press, 2008), 41.
} 
anggota populasi mempunyai kesempatan yang sama untuk dipilih menjadi sampel. ${ }^{36}$

Instrumen pengumpulan data yang menentukan berhasil atau tidaknya suatu penelitian untuk memperoleh data yang relevan dan akurat. Adapun metode pengumpulan data dalam penelitian ini yaitu: angket, observasi, dokumentasi dan wawancara.

Instrumen penelitian sangat menentukan keberhasilan dari suatu penelitian. Ibnu Hajar mengungkapkan bahwa "instrumen penelitian adalah alat ukur yang digunakan untuk mendapatkan informasi kuantitatif tentang variasi karakteristik variabel secara objektif." ${ }^{37}$ Oleh karena itu, dalam penelitian ini penulis menggunakan beberapa instrumen untuk menggunakan data lapangan yaitu observasi dan angket (kuisioner).

Analisis data adalah penyelididkan dan penguraian terhadap suatu data untuk mengetahui keadaan yang sebenar- benarnya. Dalam analisis data ini, data yang telah terkumpul atau diperoleh, baik yang berkaitan denga kompetensi kepribadian guru maupun tentang motivasi belajar siswa, dikelompokan msingmasing secara terpisah. Adapun langkah-langkah analisis data yang dilakukan peneliti adalah: persiapan, tabulasi, analisa data korelasi.

\footnotetext{
${ }^{36}$ Tulus Winarsunu, Statistik dalam penelitian Psikologi dan Pendidikan (Malang: UMM Press, 2007), 16.

${ }^{37}$ Ibnu Hajar, Dasar-Dasar Metodologi Penelitian, 160.
}

Dirasah, Vol. 2, No. 1, Februari 2019 


\section{Hasil Penilitian}

\section{Religiusitas orang tua}

Adapun deskripsi data religiusitas orang tua siswa dengan menggunakan Aplikasi SPSS 20 didapatkan hasil sebagai berikut:

Tabel Deskripsi Data Religiusitas Orang Tua

\begin{tabular}{llll}
\hline \multicolumn{3}{c}{ Descriptives } \\
\hline Mean & Statistic & Std. Error \\
\hline 95\% Confidence Lower Bound & 130.7184 & .858 \\
Interval for Mean Upper Bound & 129.0152 & \\
5\% Trimmed Mean & 132.4217 & \\
Median & 130.8862 & \\
Variance & 131.0000 & \\
Std. Deviation & 75.949 & \\
Minimum & 8.71489 & \\
Maximum & 107.00 & \\
Range & 147.00 & \\
Interquartile Range & 40.00 & \\
Skewness & 13.00 & \multirow{2}{*}{.ond } \\
Kurtosis & $-.226-$ & .472 \\
\hline
\end{tabular}

Dari tabel di atas diperoleh deskripsi data religiusitas orang tua siswa dengan aplikasi SPSS 20 dengan nilai rata-rata (mean) sebesar 130, 718 dan standart deviasinya sebesar 8,715. Hasil tersebut selanjutnya dikonversikan ke dalam 5 skala penilaian yang disajikan pada tebel berikut ini:

\begin{tabular}{lll}
\multicolumn{3}{c}{ Tabel Pedoman Konversi Nilai ${ }^{38}$} \\
\hline $\begin{array}{l}\text { Pedoman } \\
\text { konversi }\end{array}$ & Perhitungan & Hasil \\
\hline $\mathrm{M}+(1,5 . \mathrm{SD})$ & $130,718+(1,5.8,715)$ & 144 \\
\hline $\mathrm{M}+(0.5 . \mathrm{SD})$ & $130,718+(0.5 .8,715)$ & 135 \\
\hline $\mathrm{M}-(0,5 . \mathrm{SD})$ & $130,718-(0,5.8,715)$ & 126 \\
\hline $\mathrm{M}-(1,5 . \mathrm{SD})$ & $130,718-(1,5.8,715)$ & 118 \\
\hline
\end{tabular}

Dengan berpedoman pada konversi di atas, maka dapat dikelompokan kedalam beberapa ketegori berikut ini:

${ }^{38}$ Suharsimi Arikunto, Dasar-Dasar Evaluasi Pendidikan (Jakarta: Bumi Aksara, 2008), 256. 
Tabel Interpretasi Konversi Religiusitas Orang Tua

\begin{tabular}{ll}
\hline Skor & Kategori \\
\hline$\geq 144$ & Sangat Baik \\
\hline $135 \leq$ Skor $<144$ & Baik \\
\hline $126 \leq$ Skor $<135$ & Cukup \\
\hline $118 \leq$ Skor $<126$ & Kurang \\
\hline$<118$ & Sangat kurang
\end{tabular}

Berdasarkan perhitungan pedoman konversi di atas, data yang diperoleh dapat dikelompokan kedalam lima kategori di antaranya; yang termasuk kategori sangat kurang ada 8 responden dengan prosentase 7,78\%, kategori kurang sebanyak 21 responden dengan prosentase $20,1 \%$, kategori cukup sebanyak 41 responden dengan prosentase $39,8 \%$, kategori tinggi sebanyak 25 responden dengan prosentase $24,3 \%$. kategori sangat baik sebanyak 8 responden dengan prosentase $7,78 \%$.

Selanjutnya, untuk mengetahui kriteria tingkat religiusitas orang tua juga digunakan kategorisasi menggunakan absolute score. Kategori absolute score ditentukan dengan menggunakan skor angket yang tertinggi dan terendah yang dapat diperoleh dari responden. Kemudian dari selisih skor tertinggi dan terendah tersebut dibagi dengan jumlah kategori yang diinginkan, dan hasilnya digunakan sebagai interval dalam membuat pedoman kategorisasi.

Diketehui jumlah item pertanyan yang valid dari instrumen religiusitas orang tua adalah 37 dengan 4 pilihan jawaban. Sehingga skor angket tertingginya adalah $(37 x 4)=148$ dan skor terendahnya 37. Selisih keduanya adalah 148 . Kemudian hasil dari selisih ini dibagi dengan jumlah kategori yang telah ditentukan yakni 5. Hasilnya setelah dibulatkan didapatkan 30, sehingga dapat dikelompokkan kedalam kategori absolute score berikut ini:

Tabel Interpretasi Absolute Score Religiusitas Orang Tua

\begin{tabular}{lll}
\hline No. & Perhitungan & Kategori \\
\hline 1. & $37-59$ & Sangat kurang \\
\hline 2. & $60-81$ & Kurang \\
\hline 3. & $82-104$ & Cukup \\
\hline 4. & $105-127$ & Baik \\
\hline 5. & $128-148$ & Sangat baik \\
\hline
\end{tabular}

Dari perhitungan di atas, dapat dinyatakan bahwa religiusitas orang tua dikategorikan sangat baik, hal itu didaptkan dengan berpedoman pada 
perhitungan “Absolutel Score”di atas dengan nilai rata-rata (mean) sebesar 130, 718 yang masuk pada interval kategori sangat baik.

\section{Tingkat religiusitas siswa (variabel terikat)}

Adapun deskripsi data religiusitas dengan menggunakan Aplikasi SPSS 20 didapatkan hasil sebagai berikut:

\begin{tabular}{|c|c|c|c|}
\hline \multicolumn{4}{|c|}{ Descriptives } \\
\hline & & Statistic & Std. Error \\
\hline \multirow{13}{*}{ r.siswa } & Mean & 127.97 & .719 \\
\hline & 95\% Confidence Lower Bound & 126.54 & \\
\hline & Interval for Mean Upper Bound & 129.39 & \\
\hline & $5 \%$ Trimmed Mean & 128.06 & \\
\hline & Median & 128.00 & \\
\hline & Variance & 53.303 & \\
\hline & Std. Deviation & 7.3008 & \\
\hline & Minimum & 112.00 & \\
\hline & Maximum & 144.00 & \\
\hline & Range & 32.00 & \\
\hline & Interquartile Range & 10.00 & \\
\hline & Skewness & $-.253-$ & .238 \\
\hline & Kurtosis & $-.482-$ & .472 \\
\hline
\end{tabular}

Dari tabel di atas diperoleh deskripsi data religiusitas siswa dengan aplikasi SPSS 20 dengan nilai rata-rata (mean) sebesar 127.971 dan standart deviasinya sebesar 7,301. Dari hasil tersebut selanjutnya dikonversikan kedalam 5 skala penilaian yang disajikan pada tebel berikut ini:

\section{Tabel Pedoman Konversi Nilai ${ }^{39}$}

\begin{tabular}{lll}
\hline Pedoman konversi & Perhitungan & Hasil \\
\hline $\mathrm{M}+(1,5 . S D)$ & $127.971+(1,5.7,301)$ & 140 \\
\hline $\mathrm{M}+(0.5 . \mathrm{SD})$ & $127.971+(0.5 .7,301)$ & 132 \\
\hline $\mathrm{M}-(0,5 . \mathrm{SD})$ & $127.971-(0,5.7,301)$ & 124 \\
\hline $\mathrm{M}-(1,5 . \mathrm{SD})$ & $127.971-(1,5.7,301)$ & 117 \\
\hline
\end{tabular}

Dengan berpedoman pada konversi di atas, maka dapat dikelompokan kedalam beberapa ketegori berikut ini:

${ }^{39}$ Suharsimi Arikunto, Dasar-Dasar Evaluasi Pendidikan (Jakarta: Bumi Aksara, 2008), 256. 
Tabel Interpretasi Konversi Religiusitas Orang Tua

\begin{tabular}{ll}
\hline Skor & Kategori \\
\hline$\geq 139$ & Sangat Baik \\
\hline $132 \leq$ Skor $<139$ & Baik \\
\hline $124 \leq$ Skor $<132$ & Cukup \\
\hline $117 \leq$ Skor $<124$ & Kurang \\
\hline$<117$ & Sangat kurang \\
\hline
\end{tabular}

Berdasarkan perhitungan pedoman konversi di atas, data yang diperoleh dapat dikelompokan kedalam lima kategori diantaranya; yang termasuk kategori sangat kurang ada 12 responden dengan prosentase $11.65 \%$, kategori kurang sebanyak 22 responden dengan prosentase $21.35 \%$, kategori cukup sebanyak 49 responden dengan prosentase $47.57 \%$, kategori baik sebanyak 15 responden dengan prosentase $14.56 \%$. kategori sangat baik sebanyak 5 responden dengan prosentase $4.86 \%$.

Selanjutnya, untuk mengetahui kriteria tingkat religiusitas siswa juga digunakan kategorisasi menggunakan absolute score. Kategori absolute score ditentukan dengan menggunakan skor angket yang tertinggi dan terendah yang dapat diperoleh dari responden. Kemudian dari selisih skor tertinggi dan terendah tersebut dibagi dengan jumlah kategori yang diinginkan, dan hasilnya digunakan sebagai interval dalam membuat pedoman kategorisasi.

Diketehui jumlah item pertanyan yang valid dari instrumen religiusitas siswa adalah 37 dengan 4 pilihan jawaban. Sehingga skor angket tertingginya adalah $(37 \times 4)=148$ dan skor terendahnya 37 . Selisih keduanya adalah 111. Kemudian hasil dari selisih ini dibagi dengan jumlah kategori yang telah ditentukan yakni 5. Hasilnya setelah dibulatkan didapatkan 22, sehingga dapat dikelompokkan ke dalam kategori absolute score berikut ini:

Tabel Interpretasi Absolute Score Religiusitas Siswa

\begin{tabular}{lll}
\hline No. & Perhitungan & Kategori \\
\hline 1. & $37-59$ & Sangat kurang \\
\hline 2. & $60-81$ & Kurang \\
\hline 3. & $82-104$ & Cukup \\
\hline 4. & $105-127$ & Baik \\
\hline 5. & $128-148$ & Sangat baik \\
\hline
\end{tabular}

Dari perhitungan di atas dapat dinyatakan bahwa religiusitas siswa dikategorikan sangat baik, hal itu didaptkan dengan berpedoman pada 
perhitungan “Absolutel Score”di atas dengan nilai rata-rata (mean) sebesar 127, 971 (dibulatkan menjadi 128) yang masuk pada interval kategori sangat baik.

\section{Hubungan religiusitas orang tua dan religiusitas siswa}

Sebelum menganalisis hubungan tingkat Religiusitas Orang tua dan Religiusitas Siswa terlebih dahulu peneliti melakukan uji prasyarat, yaitu uji normalitas data dengan menggunakan software SPSS versi 20.

\section{1. uji normalitas data}

Untuk mengetahui normalitas data, maka penulis menggunakan software SPSS versi 20 hasilnya dapat dilihat pada tabel di bawah ini.

Tabel Uji Normalitas Data

\begin{tabular}{lllllll}
\hline \multicolumn{7}{c}{ Tests of Normality } \\
\hline \multicolumn{7}{c}{ Kolmogorov-Smirnov } \\
\cline { 2 - 7 } & Statistic & Df & Sig. & Statistic & df & Sig. \\
\hline r.ortu & .060 & 103 & $.200^{*}$ & .985 & 103 & .304 \\
\hline r.siswa & .069 & 103 & $.200^{*}$ & .984 & 103 & .231 \\
\hline *. This is a lower bound of the true significance. \\
\hline a. Lilliefors Significance Correction \\
\hline
\end{tabular}

Untuk menguji normalitas, digunakan skor Sig yang terdapat pada hasil perhitungan Kolmogorof-Smirnov. Bila angka Sig pada uji normalitas dengan uji kolmogorov smirnov lebih besar atau sama dengan 0,05, maka data tersebut berdistribusi normal. Akan tetapi apabila kurang, maka data tersebut tidak berdistribusi normal. ${ }^{40}$

Karena variabel religiusitas orang tua memiliki nilai Sig 0.200 yang artinya berada di atas 0.05 maka distribusinya normal. Sedangkan untuk variabel Religiusitas siswa karena Sig adalah 0.200 yang jauh berada di atas 0,05 maka distribusinya juga normal.

${ }^{40}$ Ali Anwar, Statistika Untuk Penelitian (Kediri:IAIT Press, 2007), 39 
Hal ini dapat dilihat juga pada gambar di bawah ini:

\section{Gambar Grafik Normalitas Religiusitas Orang Tua}

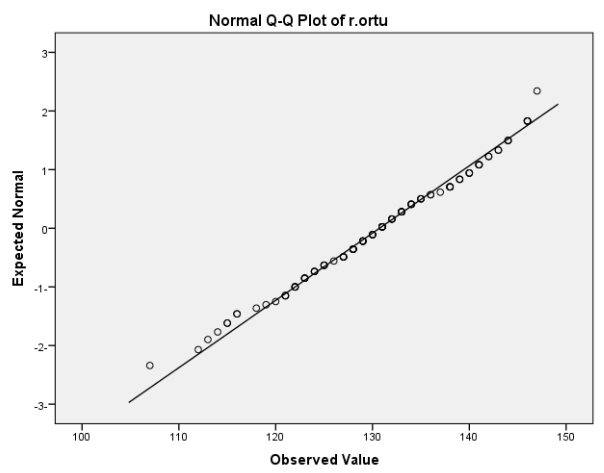

\section{Gambar Grafik Normalitas Religiusitas Siswa}

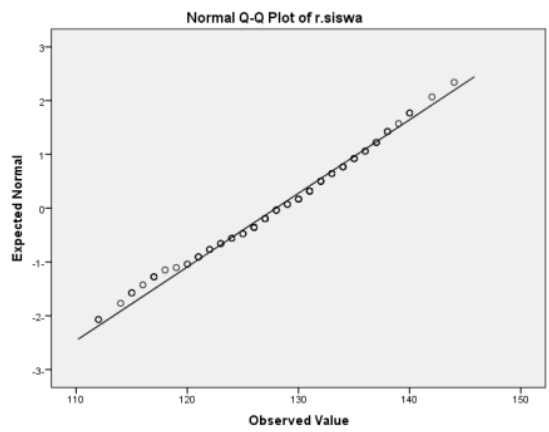

Hal ini juga dapat dilihat pada gafik Normal Q-Q Plot maupun Detrended Normal Q-Q Plot. Untuk Normal Q-Q plot, apabila sebaran data variabel itu bergerombol di sekitar garis uji yang mengarah ke kanan atas dan tidak terletak jauh dari sebaran data, maka data tersebut berdistribusi normal. Sementara untuk Detrended Normal Q-Q Plot, apabila datanya tidak membentuk suatu pola tertentu atau menyebar secara acak, maka data tersebut berdistribusi data normal. ${ }^{41}$ Sesuai dengan gambar di atas, maka hasil uji dengan dua model grafik di bawah ini juga menunjukkan data dari dua variabel di atas berdistribusi normal.

${ }^{41}$ Ibid, 40.

Dirasah, Vol. 2, No. 1, Februari 2019 


\section{Pengujian Hipotesis}

Proses pengujian data diarahkan untuk menguji hipotesis dalam penelitian. Sebelum menguji hipotesis, terlebih dahulu diajukan hipotesis:

Ho : Tidak ada hubungan tingkat religiusitas orang tua dan tingkat religiusitas siswa kelas XI MAN Prambon.

$\mathrm{Ha}$ : Ada hubungan tingkat religiusitas orang tua dan tingkat religiusitas siswa kelas XI MAN Prambon.

Setelah dipaparkan hipotesis dan data di atas, maka untuk mengetahui Adakah hubungan tingkat religiusitas orang tua dan tingkat religiusitas siswa kelas XI MAN Prambon dengan menggunakan aplikasi SPSS 20.

Adapun hasil dari penghitungan menggunakan SPSS versi 20. sebagai berikut:

Tabel Deskriptif Statistik religiusitas orang tua dan religiusitas siswa Descriptive Statistics

\begin{tabular}{llll}
\hline & Mean & Std. Deviation & N \\
\hline r.ortu & 130.7184 & 8.71489 & 103 \\
r.siswa & 127.9709 & 7.30089 & 103 \\
\hline
\end{tabular}

Berdasarkan output di atas, maka diketahui bahwa rata-rata skor religiusitas orang tua adalah 130,718 dengan standart deviasi 8,715. Sedangkan rata-rata skor religiusitas siswa adalah 127,971 dengan standart deviasi 7,301. Sampel penelitian yang digunakan berjumlah 103 .

Tabel Uji Korelasi Religiusitas Orang Tua dan Religiusitas Siswa Correlations

\begin{tabular}{llll}
\hline & & r.ortu & r.siswa \\
\hline \multirow{2}{*}{ r.ortu } & Pearson Correlation & 1 & $.765^{* *}$ \\
& Sig. (2-tailed) & & .000 \\
& $\mathrm{~N}$ & 103 & 103 \\
& Pearson Correlation & $.765^{* *}$ & 1 \\
r.siswa & Sig. (2-tailed) & .000 & \\
& $\mathrm{~N}$ & 103 & 103 \\
**. Correlation is significant at the 0.01 level (2-tailed).
\end{tabular}

Dari data di atas dapat diketahui juga bahwa Korelasi religiusitas orang tua dengan religiusitas siswa adalah 0.765 . Sedangkan untuk mengetahui iterpretasi dari nilai korelasi tersebut dapat dilihat pada tebel berikut: 
Tabel Interpretasi Koefisien Korelasi ${ }^{42}$

\begin{tabular}{ll}
\hline Interval koefisien & Interpretasi \\
\hline $0.00-0,199$ & Sangat Rendah \\
\hline $0,20-0,399$ & Rendah \\
\hline $0,40-0,599$ & Sedang \\
\hline $0,60-0,799$ & Kuat \\
\hline $0,80-1,000$ & Sangat Kuat \\
\hline
\end{tabular}

Dengan berpedoman tabel interpretasi korelasi di atas, maka dapat disimpulkan bahwa arah korelasi tingkat religiusitas orang tua dan tingkat religiusitas siswa kelas XI MAN Prambon memiliki korelasi yang kuat.

Sedangkan untuk pengambilan keputusan statistik, dapat digunakan dua cara, yaitu:

1. Koefisien Korelasi dibandingkan dengan nilai $r_{\text {tabel }}$ (korelasi tabel)

Pengambilan kesimpulan dilakukan dengan membandingkan nilai Koefisien Korelasi terhadap nilai $r_{\text {tabel }}$ pada tingkat kesalahan $5 \%$ dengan dk jumlah sample dikurangi 2. Apabila Koefisien Korelasi memiliki nilai lebih besar atau sama dengan $r$ tabel maka Ho ditolak dan Ha diterima, sedangkan apabila Koefisien Korelasi memiliki nilai lebih kecil dari $r$ tabel maka Ho diterima dan Ha ditolak. (Apabila Koefisien Korelasi $>\mathrm{r}$ tabel Maka ada korelasi yang signifikan dan Ha Diterima). Dari perhitungan dengan menggunakan aplikasi SPSS 20 diketahui bahwa Koefisien korelasi adalah 0.765 , sedangkan nilai $r$ tabel $(\alpha=0,05 ; \mathrm{dk}$ : 101) yaitu sebesar 0,195 . Karena Koefisien Korelasi $>r_{\text {tabel }}$ Maka ada korelasi yang signifikan dan Ha Diterima. Dengan kata lain Ada hubungan yang signifikan tingkat religiusitas orang tua dan tingkat religiusitas siswa kelas XI MAN Prambon.

2. Melihat Sig

Pengambilan kesimpulan dilakukan dengan melihat nilai Sig. Apabila nilai Sig memiliki nilai kurang dari 0,05 maka ada korelasi yang signifikan atau dengan kata lain Ho ditolak dan Ha diterima.

Berdasarkan hasil perhitungan dengan SPSS 20 diperoleh nilai Sig sebesar 0,000 (kurang dari 0,05). Oleh karenanya, dapat disimpulkan bahwa ada korelasi yang signifikan atau dengan kata lain Ada hubungan yang

${ }^{42}$ Ali Anwar, Statistika Untuk Penelitian Pendidikan Dan Aplikasinya Dengan SPSS dan Exel (Kediri:IAIT PRESS, 2009), 104

Dirasah, Vol. 2, No. 1, Februari 2019 
signifikan tingkat religiusitas orang tua dan tingkat religiusitas siswa kelas XI MAN Prambon.

Dengan diketahuinya jumlah koefisien korelasi sebesar 0,765 juga dapat digunakan untuk menentukan besarnya koefisien determinasi. Koefisien determinasi merupakan proporsi variabilitas dalam suatu data yang dihitung didasarkan pada model statistik. Koefisien determiniasi dalam penelitian ini juga dapat diartikan sebagai besarnya pengaruh variabel religiusitas orang tua (X) terhadap variabel religiusitas anak (Y). Rumus untuk menghitung koefesien determinasi (KD) adalah

$$
\begin{aligned}
& \mathrm{KD}=\mathrm{r}^{2} \times 100 \% \\
& \mathrm{KD}=(0,765)^{2} \times 100 \% \\
& \mathrm{KD}=58,52 \%
\end{aligned}
$$

Berdasarkan perhitungan di atas dapat diketahui bahwa koefisien determinasi (KD) yaitu sebesar 58,52\%. Hal tersebut menunjukkan pengaruh religiusitas orang tua terhadap religiusitas anak adalah sebesar 58,52\%. Sedangkan sisanya dipengaruhi oleh faktor lain.

\section{Pembahasan}

Untuk menjawab rumusan masalah yang ketiga yaitu Hubungan Tingkat Religiusitas Orang Tua Dengan Tingkat Religiusitas Siswa Kelas XI MAN Prambon tahun pelajaran 2013-2014, maka penulis telah mengumpulkan data tentang Tingkat Religiusitas Orang Tua Dengan Tingkat Religiusitas Siswa Kelas XI MAN Prambon dengan menyebarkan angket kepada sempel yang telah ditentukan sebelumnya yang berjumlah 103 orang tua siswa dan 103 siswa MAN I Prambon. Hasil angket dari kedua kategori penggunaan media tersebut menunjukan bahwa tingkat religiusitasnya tergolong sangat baik berdasarkan pencocokan absolute skor nilai mean 127,971untuk siswa dan 130,718 untuk orang tua.

Selanjutnya setelah dilakukan analisis uji hipotesis diperoleh nilai korelasi product moment sebesar 0,765 . Setelah diambil interpretasikan ternyata korelasi tingkat religiusitas orang tua dan tingkat religiusitas siswa kelas XI MAN Prambon memiliki korelasi yang kuat. Selain itu dari pengambilan keputusan statistik yang telah dilakukan peneliti melalui dua cara yaitu dengan membandingkan Koefisien Korelasi dengan nilai $r$ tabel (korelasi tabel) serta dengan Melihat Sig didapatkan bahwa koefisien korelasi lebih tinggi dari nilai $r$ tabel dan juga nilai Sig di bawah 0,05 yang berarti bahwa Ha diterima dan Ho 
ditolak. Dengan kata lain terdapat hubungan yang signifikan tingkat religiusitas orang tua dan tingkat religiusitas siswa kelas XI MAN Prambon.

Hal ini sejalan dengan teori yang dikemukakan oleh Thoules, yang menyatakan bahwa salah satu faktor yang mempengaruhi tingkat religiusitas seseorang adalah faktor sosial yang mencakup semua pengaruh sosial dalam perkembangan sikap keagamaan yaitu pendidikan atau pengetahuan tentang agama, tradisi-tradisi sosial untuk menyesuaikan diri dengan berbagai pendapat dan sikap yang disepakati oleh lingkungan seperti kondisi masyarakat dan keluarga. ${ }^{43}$ Selain itu temuan penelitian juga selaras denga teori yang diungkapkan oleh Albert Bandura melalui teori pembelajaran sosial serta teori modeling. Menurut Albert Bandura tingkah laku manusia bukan semata-mata reflex otomatis atas stimulus, melainkan juga akibat reaksi yang timbul akibat interaksi antar lingkungan dengan skema kognitif manusia itu sendiri. Prinsip dasar belajar hasil temuan Bandura termasuk belajar sosial dan moral. ${ }^{44}$

Ridwan Munir mengatakan bahwa:

Teori Pembelajaran Sosial merupakan perluasan dari teori belajar perilaku yang tradisional (behavioristik). Teori pembelajaran sosial ini dikembangkan oleh Albert Bandura. Teori ini menerima sebagian besar dari prinsip-prinsip teoriteori belajar perilaku, tetapi memberikan lebih banyak penekanan pada kesan dan isyarat-isyarat perubahan perilaku, dan pada proses-proses mental internal. Jadi dalam teori pembelajaran sosial kita akan menggunakan penjelasanpenjelasan reinforcement eksternal dan penjelasan-penjelasan kognitif internal untuk memahami bagaimana belajar dari orang lain. ${ }^{45}$

Dalam pandangan belajar sosial manusia itu tidak didorong oleh kekuatankekuatan dari dalam dan juga tidak dipengaruhi oleh stimulus-stimulus lingkungan. Teori belajar sosial menekankan bahwa lingkungan-lingkungan yang dihadapkan pada seseorang secara kebetulan; lingkungan-lingkungan itu kerap kali dipilih dan diubah oleh orang itu melalui perilakunya sendiri. Menurut Bandura, sebagaimana dikutip oleh Surya Subrata bahwa "sebagian besar

\footnotetext{
${ }^{43}$ R.H. Thoules, Pengantar Psikologi Agama (Jakarta: Rajawali Press, 2000), 72.

${ }^{44}$ Ridwan Muzir, Personality Theories: Melacak Kepribadian Anda bersama Psikolog Dunia (Yogyakarta: Ar-Ruz Media, 2008), 239.

45 Ibid, 239-240.
}

Dirasah, Vol. 2, No. 1, Februari 2019 
manusia belajar melalui pengamatan secara selektif dan mengingat tingkah laku orang lain". ${ }^{46}$ Albert Bandura dan Richard Walters yang melakukan eksperimen pada anak-anak yang juga berkenaan dengan peniruan. Hasil eksperimen mereka mendapati, bahwa peniruan dapat berlaku hanya melalui pengamatan terhadap perilaku model (orang yang ditiru) meskipun pengamatan itu tidak dilakukan terus menerus. Proses belajar semacam ini disebut "observational learning” atau pembelajaran melalui pengamatan. ${ }^{47}$

Penerapan Teori Bandura dalam Pembelajaran Proses pembentukan perilaku religius diantaranya adalah dengan modelling. Kalau siapapun yang ada di rumah atau di lingkungan anak sudah terbiasa dengan lingkungan religius sejak kecil maka hal ini akan diobservasi oleh anak secara terus menerus dalam hidupnya. Kemudian anak ini difasilitasi dengan banyak media ibadah baik yang alami maupun buatan untuk mendorong minat religiusnya, misalnya berupa buku bacaan islami, peralatan sholat dan kelengkapannya, serta mengaji di Surau atau Masjid.

Orang tua berperan ganda, sebagai model sekaligus sebagai pamong belajar. Tanpa ada ancaman, hukuman, ketegangan, ketakutan akan membuat anak nyaman, tenang, untuk belajar dengan pamongnya. Dominansi kasih sayang, kelembutan, contoh yang nyata, kejujuran, kesantunan, pujian, penghargaan, senyuman akan sangat mendorong munculnya perilaku yang diharapkan. Kesinambungan proses seperti ini akan mengkristal dalam jiwa dan pikir anak sehingga menjadi perilaku yang permanen dalam hidupnya.

Jadi dapat disimpulkan bahwa individu belajar mengumpulkan informasi melalui observasi, baik tentang konsekuensi perilakunya sendiri maupun perilaku individu lain. Informasi yang diperoleh kemudian diterapkan di berbagai situasi yang membutuhkan perilaku tersebut. Perilaku yang mendapat reinforcement akan disimbolisasikan ke dalam memori sehingga informasi tersebut dapat membantu individu menentukan suatu perilaku tertentu pada situasi tertentu yang menghasilkan konsekuensi tertentu pula.

\section{Penutup}

Dari uraian di atas telah dipaparkan oleh peneliti tentang Hubungan Tingkat Religiusitas Orang Tua Dengan Tingkat Religiusitas Siswa Kelas XI MAN

\footnotetext{
${ }^{46}$ Surya Suryabrata, Psikologi Pendidikan (Jakarta: Rajawali Pers, 2010), 59.

${ }^{47}$ Ridwan Muzir, Personality Theories: Melacak Kepribadian, 240.
} 
Prambon tahun pelajaran 2013-2014. Dari hasil penelitian dan pembahasan sampai analisisnya, maka dapat disimpulkan sebagai berikut:

1. Tingkat religiusitas orang tua siswa kelas XI MAN Prambon dikategorikan sangat baik berdasarkan nilai mean sebesar 130, 718 yang berpedoman pada kriteria absolute score.

2. Tingkat religiusitas siswa kelas XI MAN Prambon dikategorikan sangat baik berdasarkan nilai mean sebesar 127.971 yang berpedoman pada kriteria absolute score.

3. Terdapat hubungan yang signifikan tingkat religiusitas orang tua dan tingkat religiusitas siswa kelas XI MAN Prambon dengan nilai korelasi product moment sebesar 0.765 yang lebih besar dibandingkan nilai $r$ tabel serta nilai Sig di bawah 0,05 yaitu sebesar 0,000 .

\section{Daftar Pustaka}

Agustin, Ary Ginanjar. Rahasia Sukses Membangkitkan ESQ Power. Jakarta: Arga, 2006.

Ahmadi, Abu. Psikologi Belajar. Jakarta: Rineka Cipta, 2004.

Ahmadi, Rulam. Memahami Metodologi Penelitian Kualitatif. Malang: Universitas Negeri Malang, 2005.

al-Bukhari, Imam. Shahih Bukhari. Beirut: Dar Ahya al-Turarts al-Arabiy, tt.

Aly, Hery Noer. Ilmu Pendidikan Islam. Jakarta: Logos Wacana Ilmu, 1999.

Ancok, Djamaludin \& Fuat Nashori Suroso, Psikologi Islam: Solusi Islam atas Problem-problem Psikologi. Yogyakarta: Pustaka Pelajar, 2000.

Anwar, Ali. Statistika Untuk Penelitian Pendidikan Dan Aplikasinya Dengan SPSS dan Exel. Kediri:IAIT PRESS, 2009.

Arikunto, Suharsimi. Prosedur Penelitian Suatu Pendekatan Praktek (Jakarta: Rineka Cipta, 2006. . Dasar-Dasar Evaluasi Pendidikan. Jakarta: Bumi Aksara, 2008.

Dirasah, Vol. 2, No. 1, Februari 2019 
Arief, Armai. Pengantar Ilmu dan Metodologi Pendidikan Islam. Jakarta: Ciputat Press, 2002.

Astuti, Kamsih. Psikologi Sosial. Yogyakarta: Universitas Mercu Buana, 2009.

Azwar, Saifudin. Metode Penelitian. Yogyakarta: Pustaka Pelajar, 1998. . Penyusunan Skala Psikologi. Yogyakarta: Pustaka Pelajar, 2002.

Bastaman, H.D. Integrasi Psikologo dalam Islam. Yogyakarta: Pustaka Pelajar, 1995.

Boeree, George. Personality Theories: Melacak Kepribadian Anda bersama Psikolog Dunia. Terj. Ridwan Muzir. Yogyakarta: Ar-Ruz Media, 2008.

Bungin, M. Burhan. Metode Penelitian Kuantitatif. Jakarta : Kencana, 2005.

Dahama dan Op Batnabar, Education and Communication for Development. New Delhi: Oxford and IBH Publishing Co, 1980.

Daradjat, Zakiyah. Ilmu Jiwa Agama. Jakarta: Bulan Bintang, 1990. . Pendidikan Dalam Keluarga dan Sekolah. Jakarta: Ruhama, 1999.

Departemen Agama Republik Indonesia. Alqur'an dan Terjemahannya. Jakarta: J-Art, 2004.

Gufron, M Nur \& Rini Risnawati, Teori-teori Psikologi. Malang: Ar-Ruzz Media, 2010.

Hadi, Sutrisno. Metodologi Research I. Yogyakarta: Penerbitan Psikologi UGM,1994.

Hamid, Muhammad Muhyiddin Abdul. Sunan Abi Dawud, (Indonesia: Maktabah Dahlan, I: t.t.

Hanan dan Mimi Martini. Penelitian Terapan. Yogyakarta: Gajah Mada Press, 1996. 
Hendropuspito, Sosiologi Agama. Yogyakarta: Kanisius dan BPK Gunung Mulia, 1990.

Iin Sri Rahayu, "Hubungan Antara Kematangan Beragama Dengan Daya Tahan Terhadap Stres Pada Mahasiswa." Jurnal Psikologi. Malang: Fakultas Psikologi UNM, 2006.

Jalaluddin, Psikologi Agama. Jakarta: Raja Grafindo Persada, 1997.

John W. Creswell, Research Design: Qualitative, Quantitative and mixed Approach (Terj). USA: Sage Publication, 1994.

Jick, TD. Mixing Qualitative and quantitative methods: Triangulation in action. USA: Administrative Science Quarterly, 1979.

Kerlinger, Fred N. Azas-Azas Penellitian Behavioral, terj. Landung R. Simatupan. Yogyakarta: UGM Press, 2006.

Latipun, Psikologi Eksperimen. Malang: UMM Press, 2008.

Madjidi, Busyairi. Konsep Pendidikan Para Filosof Muslim. Yogyakarta: AlAmin Press, 1991.

Margono. Metodologi Penelitian Pendidikan. Jakarta: Asdi Mahasatya, 2005.

Moleong, Lexy J. Metodologi Penelitian Kualitatif. Bandung: Remaja Rosdakarya, 2009.

Muhaimin, Paradigma Pendidikan Islam (upaya mengefektifkan Pendidikan Agama Islam di sekolah). Bandung: Remaja Rosdakarya, 2004.

Muhibbinsyah. Psikologi Belajar. Jakarta: Rajawali Pers, 2009.

Nata, Abudin. Filsafat Pendidikan Islam. Jakarta: Logos Wacana Ilmu, 1997. . Manajemen Pendidikan (mengatasi kelemahan Pendidikan Islam di Indonesia). Jakarta: Kencana, 2003.

Neuman, William Lawrence. Social Research Method, Qualitative and Quantitative Approaches, $5^{\text {th }}$ edition. USA: Allyn \& Bacon, 2003. 
Partanto, Pius A. dan M. Dhlan Al-Barry, Kamus Ilmiah Populer. Surabaya: Arkola, 1994.

Prasetyo, Bambang. Metode penelitian Kuantitatif. Jakarta: Rajawali Press, 2010.

Purwanto, M. Ngalim. Ilmu Pendidikan Teoritis dan Praktis. Bandung: Remaja Rosdakarya, 2002.

Stark, R. dan C.Y. Glock, American Piety: The Nature of Religious Comitment. California: University of California Press, 1968.

Sudjiono, Anas. Pengantar Evaluasi Pendidikan. Jakarta: Grafindo Persada, 1998.

Surachmat, Winarno. Dasar dan Teknik Research. Bandung: Tarsito, 2007.

Suryabrata, Surya. Psikologi Pendidikan. Jakarta: Rajawali Pers, 2010.

Tafsir, Ahmad. Ilmu Pendidikan Dalam Perspektif Islam. Bandung: Remaja Rosdakarya, 1994.

Thoules, R.H. Pengantar Psikologi Agama. Jakarta: Rajawali Press, 2000.

Tina Afiatin, "Religiusitas Remaja: Study tentang kehidupan beragama di Daerah Istimewa Yogyakarta." Jurna Psikologi, II: 1998.

Ulwan, Abdullah Nashih. Pendidikan Anak Menurut Islam, Terj. Amin. Bandung: Remaja Rosdakarya, 1992.

Universitas Muhamadiyah Malang, Psikologi Kepribadian. Malang:UMM Press, 2011.

Undang-undang RI Nomor 20 Tahun 2003 tentang Sisdiknas Beserta Penjelasannya. Bandung: Bulan Bintang, 2003.

Usman, Husaini dan Purnomo Setiadi, Pengantar Ststistika. Jakarta: Bumi Aksara, 2006. 
Winarsunu, Tulus. Statistik dalam Penelitian Psikologi dan Pendidikan. Malang: UMM Press, 2007.

Copyright (C) 2019 Journal Dirasah: Vol. 2, No. 1, Februari 2019, p-ISSN: 2615-0212, e-ISSN; 2621-2838

Copyright rests with the authors

Copyright of Jurnal Dirasah is the property of Jurnal Dirasah and its content may not be copied or emailed to multiple sites or posted to a listserv without the copyright holder's express written permission. However, users may print, download, or email articles for individual use. https://ejournal.iaifa.ac.id/index.php/dirasah 